\title{
Rice Production Determinants and Income Role for the Poverty Reduction in District Larkana, Pakistan
}

\author{
* Azad Ali Khatyan, PhD Scholar (Corresponding Author) \\ ** Prof. Dr. Muhammad Saleem Rahpoto, Professor \\ ** Dr. Ghulam Muhammad Mangnejo, Assistant Professor
}

\begin{abstract}
Poverty is a chronic problem in Pakistan. More than 25 percent of the population is still living below the poverty line. In Pakistan, rural poverty is more than urban poverty. More than 65 percent of the population is living in rural areas. They depend on farming. The purpose of this study was to determine the variables for the more production of rice crops which will increase the income of farmers and it will reduce the poverty from the farmers. The study calculated the average household income of the farmers. The area of this study was District Larkana. A Stratified sample technique was used for the sample from the four Taluka, a sample size of 100 farmers were selected. The data were analyzed by using the cobb-Douglas production function in the log transform method. Demographic results showed that farmers are less educated. The family size was mostly large and they are experienced. The average incomes of the farmers were 53960. The results of the regression revealed that model data is valid with Cronbach's alpha 0.69. Adjusted R-square 0.91 shows good variation due to selected variables. The model is significant at 0.000 values. All variables plow, fertilizer, seed Pest, Labor, Education, and experiences have a positive impact on rice production which is important for farmers' income.
\end{abstract}

Keywords: Poverty, Rice Crop, Farmers, and Income of farmers.

\section{Introduction}

An important cash crop and food in Pakistan are Rice. It contributes 0.3 percent in agriculture valueadded. The share of rice in GDP is 0.6 percent. The rice is the main staple food crop after wheat. In the year 2018, it was cropped on 2018 thousand hectares. The total production in the year was 7202 thousand tonnes. (Pakistan Bureau of Statistics)

The Table Shows the Area and Production from the year 2014-15 to 2018-19

\begin{tabular}{cccc}
\hline Year & Area (000Hectares) & Production(000Tonnes) & Yield (Kgs/Hec) \\
\hline $2014-15$ & 2891 & 7003 & 2422 \\
$2015-16$ & 2739 & 6801 & 2483 \\
$2016-17$ & 2724 & 6849 & 2514 \\
$2017-18$ & 2901 & 7450 & 2568 \\
$2018-19$ & 2810 & 7202 & 2562 \\
\hline
\end{tabular}

Source: Pakistan Bureau of Statistics

Rice is cropped and used in a belt from Japan in the East, and Pakistan in the west. More than ninety percent is the cash crop and valuable from an economic point of view. For Asian people, rice is the main food and important because it makes 70 percent of intake of Total caloric in the country of Myanmar and Bangladesh. The intake ratio in Vietnam was two-third. Indonesia's and Thailand's caloric intake was 50 percent (FAO 1999). According to the Human Development Report (UNDP 1997), at least 1.3 billion poor people which is 70 percent live in Asia. The malnutrition problem is large in the south Asia regions than in Africa. These two parts are the poorest regions in the Globe.) Svedberg 1999)

\section{Objectives of the Study}

$>\quad$ To determine the production variables.

\footnotetext{
* Department of Economics, Shah Abdul Latif University, Khairpur

** Department of Economics, Shah Abdul Latif University, Khairpur Email: rahpoto64@ hotmail.com

*** Department of Economics, Shaikh Ayaz University, Shikarpur Email: mangnejogm81@gmail.com
} 
$>\quad$ To find the socio-economic status of rice farmers.

$>\quad$ To find the income level of rice farmers.

$>\quad$ To Find the impact of income on rural poverty.

\section{Literature Review}

Dr. Noor Ahmed Memon (2013) "Rice: Important cash crop of Pakistan," Told That Pakistan is one of the major countries to produce rice in the world. Averagely Pakistan produces 6 million tonnes. It supplied 25 percent of rice to the world. Punjab and Sindh are fertile and most cultivated areas for this cash crop of rice. Millions of farmers are dependent on the rice crop. Mostly the source of employment of the area is rice crop. Rice provides 2 million tons of national food requirements. It is the main source of non-farm jobs in rural areas. Rice crop contributes to the economy as the country's foreign exchange exchequer. In 2011 the worth was \$ 2.06 billion.

(Mohammad Khalid Basheer et al., (2010) Reported that Rice is the main crop of Pakistan like wheat and cotton. it is the cash crop of Pakistan. The cultivated area for rice crops is estimated at 2,963,000 hectares. Rice is sown at a large scale in Punjab and Sindh provinces. In this regard, credit plays a very vital role in the agriculture sector like other businesses and it is very important for agricultural productivity. Credit is very helpful to remove the financial lacking and it makeable to purchase all the necessary equipment and machinery. The credit helps to improve the standard of the life of the rural farming community and it removes the gap between the income and expenditures of farmer's community related to rural areas. The government granted Rs.205 billion for agricultural credit through ZTBL and other commercial banks to issue loans to farmers to raise their productivity.

In many areas the poverty and rice farming is related. More than 900 million poor of the world are rice dependent. About 400 million people are growing the rice crop. In Asia, Africa, and Latin America about 30 million poor farm households are related to using new technologies. Due to this development, they have increased the income from $\$ 100$ to $\$ 500$ annually. It is expected that millions of farmers will be helped by 2022 to defeat poverty and another 5 million by 2030 (Ricecrp.org/reduced poverty).

Conteh et al (2012) "The influence of price on rice production in Sierra Leone Agriculture science" found that rice is an important crop that grew and used by so many people in the globe for 10000 years longer than different crops.

Africa Rice Center (2011) "Boosting Africa's rice sector research for development strategy 2011-2020 Cotonou Benin" Reported that rice is the main food item in sub-Saharan Africa. The Demand for rice was going up very speedily mostly in urban areas. It was expected that the demand would be an increase from 38 percent to 48 percent by 2030 furthermore the low-income consumers were spending more income than rich people on the rice.

Emonger et al (2009) "The rice value chain in Kenya regarding rice production. KARI, Nairobi" Told that the consumption of rice is higher than the rice production. The average rate of increase was 11 percent since 1960. Due to this rapid increase trend, rice imports were increased. The import ratio in 1960 was 23 percent, 15 percent in 1970, 53 percent in 1980, and 88 percent in 1990.

Government of Pakistan (2005-06) Rice cultivation is a valuable and important crop. It plays a crucial role to augment the economy. Rice contributes 2 million tonnes for food requirements. Rural areas depend on this crop for employment and income. It adds 6.1 percent total value added in agriculture and 1.3 percent in GDP.

\section{Research Methodology}

Area

The area of this study was district Larkana. There are four Talukas in this District. The population of the District is 1001608. It is an agriculture base for rice crops in Sindh. More than 65 percent of the population is living in rural areas. They mostly depend on agriculture. The rice and wheat crop is a major crop for the livelihood of the farmers.

\section{Data}

In this study primary data has been used. Data was collected through a questionnaire from the farmers of Larkana.

\section{Sample}

Stratified sample techniques were used in this research. The area for this study was limited. Due to time and financial matters study selected a sample size of 100 . The sample was proportionally divided into four strata for each taluka of Larkana. 
Proportional stratified sample

Formula $=\mathrm{n} / \mathrm{N} *$ total sample size

$\mathrm{N}_{1}=$ Larkana

$\mathrm{N}_{2}=$ Ratodero

$\mathrm{N}_{3}=$ Dokri

$\mathrm{N}_{4}=$ Bakrani

Total $=$

$$
\begin{array}{ll}
\mathrm{N}_{1}= & 431645 * 1001608=43 \\
\mathrm{~N}_{2}= & 226209 * 1001608=23 \\
\mathrm{~N}_{3}= & 169033 * 1001608=16 \\
\mathrm{~N}_{4}= & 174721 * 1001608=18
\end{array}
$$

\section{Data Analysis}

100

Data was analyzed with help of excel and by using statistical Pakage for social science (SPSS)

The Model

Ln $\sum \mathrm{y}=\mathrm{a}+\mathrm{X}_{1} \ln \sum$ Plowing $+\mathrm{X}_{2} \sum$ Fertilizer $+\mathrm{X}_{3} \ln \sum$ Labour $+\mathrm{X}_{4} \ln \sum$ Seed $+\mathrm{X}_{5} \ln \sum$ Where

Education $+\mathrm{X}_{6} \ln \sum$ Pest $+\mathrm{X}_{7}$ in $\sum$ EXPERIENCE $+\mathrm{u}_{\mathrm{i}}$.

$\mathrm{Y}=$ Per Acre Production

$\mathrm{X} 1=$ Plowing Rs/Acre

$\mathrm{X} 2=$ Fertilizer Rs/Acre

$\mathrm{X} 3$ = Labour man/Acre

$\mathrm{X} 4$ = Seed Rs/Acre

$\mathrm{X} 5=$ Education Years /Household

$\mathrm{X} 6=$ Pest Rs/Acre

$\mathrm{X} 7$ = Experience Year/Household

Result and Discussion

Demographic Results

Table No: 1 Age of the Farmers

\begin{tabular}{lll}
\hline Age group & Frequency & Percentage \\
\hline 25 to 30 & 5 & $5 \%$ \\
31 to 40 & 31 & $31 \%$ \\
41 to 50 & 50 & $50 \%$ \\
51 and above & 14 & $14 \%$ \\
Total & 100 & 100 \\
\hline
\end{tabular}

Table No: 01 shows the age of the farmers which revealed that most of the farmers are more than forty years as 50 percent of the respondents are in the age group of 41 to 50.14 percent of farmers are above fifty years and at a young age, the farmers' percentage was less than 5 percent. It revealed that youngsters are not taking interest in agriculture at an early age.

Table No: 02 Educations of the Farmers

\begin{tabular}{ccc}
\hline Education Group & Frequency & Percentage \\
\hline Not at all & 40 & $40 \%$ \\
Primary & 20 & $20 \%$ \\
Middle & 16 & $16 \%$ \\
Matric & 18 & $18 \%$ \\
Inter & 03 & $3 \%$ \\
Graduation & 03 & $3 \%$ \\
Masters & Nil & Nil \\
Total & 100 & 100 \\
\hline
\end{tabular}

Figures for the education revealed that 40 percent of farmers were uneducated and primary pass was 20 percent which shows the less level of education among farmers. Only 3 percent of farmers were graduates. The matric and inter percentage was 16 and 18 percent. No one was a master's in the respondents. Due to less education, new methods of agriculture were no adopted hence the per acre production was less than the potential. 
Table No: 3 Experience of the Household

\begin{tabular}{ccc}
\hline Experience/ Group & Frequency & Percentage \\
\hline 1 to 10 & 20 & $20 \%$ \\
11 to 20 & 59 & $59 \%$ \\
21 to 30 & 21 & $21 \%$ \\
Total & 100 & 100 \\
\hline
\end{tabular}

Analysis of experience in farmers shows that 20 percent of farmers have experience of 1 to 10 years. Most farmers are 11 to 20 years' experience the percentage was 59 percent and 21 percent experienced up to 30 years. The farmers were experienced but they got only traditional experience whereas they urgently need new ways of farming to enhance the production and raise their income for livelihood.

Table No 04. Family size of Farmers

\begin{tabular}{ccc}
\hline Family Group & Frequency & Percentage \\
\hline 1 to 5 & 15 & $15 \%$ \\
6 to 10 & 60 & $60 \%$ \\
11 to 15 & 25 & $25 \%$ \\
Total & 100 & 100 \\
\hline
\end{tabular}

The status of family size shows that the family size of the respondents was mostly large. 60 percent of the farmers' family was in the group of 6 to 10. It shows the more income needed for them for the large family. 25 percent of farmers have a family of 11 to 15 members and only 15 percent family have the size of 1 to 5 members.

Table No 05. Cultivation of Land.

\begin{tabular}{lll}
\hline Cultivation of land & Total land & Average land \\
\hline & 280 Acres & 2.8 Acres \\
\hline
\end{tabular}

The cultivation of the land table shows that a total of 280 acres of agricultural land were cultivated by the respondents. The average 2.8 Acres was the share of each farmer which was the main source of earning for the families of farmers.

Table No: 06 Incomes Of the Farmers.

\begin{tabular}{lll}
\hline Income & Frequency & Percentage \\
\hline 9000 to 15000 & 33 & 0.33 \\
15001 to 20000 & 19 & 0.19 \\
20001 to 25000 & 45 & 0.45 \\
25001 to 29000 & 3 & 0.3 \\
\hline
\end{tabular}

Table no: 6 Show Income of the farmer remained low as shown in the table due to the high price of inputs and a large share in the inputs. 45 percent of farmers were earning per acre from 20001 to 25000. The percentage of 9 to 15000 was 33 percent while 19 percent of farmers' income was 15001 to 20000 only 3 percent were getting more than 25000 per acre. If we take an average of the income it was about 19000 . The average land cultivation was 2.8 hence if we multiply it with average income $19000 * 2.8$ which become 53960 which is low income if the productivity of land increase than the income of farmer maybe increase.

\section{Model Analysis}

Reliability Statistics

\begin{tabular}{rr}
\hline Cronbach's Alpha & N of Items \\
\hline .696 & 8 \\
\hline
\end{tabular}

Most of the researchers consider the value of Cronbach's alpha should be greater than 0.05 here the value is 0.696 which is greater than the required value hence data is reliable for further process.

Model Summary

\begin{tabular}{ccccc}
\hline Model & $\mathrm{R}$ & R Square & Adjusted R Square & Std. An error of the Estimate \\
\hline 1 & $.959^{\mathrm{a}}$ & .920 & .914 & .06028 \\
\hline
\end{tabular}

a. Predictors: (Constant), LnExp, LnEdu, Lnplow, Lnfertilizer, LnPests, LnSeed, LnLabour

The value of adjusted $\mathrm{R}$ square shows that how much percentage regression model expresses the cause of independent variables, in this study the value of $\mathrm{R}$ square is explaining 0.914 which means there is an excellent explanation of the cause and has a reliable impact on rice production to increase the income of farmers. 


\begin{tabular}{|c|c|c|c|c|c|c|}
\hline & Model & Sum of Squares & df & Mean Square & $\mathrm{F}$ & Sig. \\
\hline \multirow{3}{*}{1} & Regression & 3.853 & 7 & .550 & 151.495 & $.000^{\mathrm{b}}$ \\
\hline & Residual & .334 & 92 & .004 & & \\
\hline & Total & 4.187 & 99 & & & \\
\hline
\end{tabular}

a. Dependent Variable: Lnincome

b. Predictors: (Constant), LnExp, LnEdu, Lnplow, Lnfertilizer, LnPests, LnSeed, LnLabour

To test the validity of the regression model we analyze the ANOVA table. F test in ANOVA should be less than 0.05 , if it is more than 0.05 models are insignificant. Here the value of the $F$ test in this table is 151.4 thus the regression model is significant. The value of significance should be less than 0.05 . The value in this study is 0.000 which is highly significant and we can consider the results of the regression model.

\section{Coefficients}

\begin{tabular}{|c|c|c|c|c|c|c|}
\hline \multirow{2}{*}{\multicolumn{2}{|c|}{ Model }} & \multicolumn{2}{|c|}{ Unstandardized Coefficients } & \multirow{2}{*}{$\begin{array}{c}\text { Standardized } \\
\text { Coefficients } \\
\text { Beta } \\
\end{array}$} & \multirow[t]{2}{*}{$\mathrm{T}$} & \multirow[t]{2}{*}{ Sig. } \\
\hline & & $\mathrm{B}$ & Std. Error & & & \\
\hline \multirow{8}{*}{1} & (Constant) & -2.520 & 1.245 & & -2.023 & .046 \\
\hline & Lnplow & .098 & .034 & .126 & 2.908 & .005 \\
\hline & Lnfertilizer & .600 & .117 & .265 & 5.140 & .000 \\
\hline & LnLabour & .522 & .319 & .164 & 1.633 & .106 \\
\hline & LnSeed & .632 & .177 & .356 & 3.579 & .001 \\
\hline & LnEdu & .013 & .010 & .059 & 1.361 & .177 \\
\hline & LnPests & .158 & .181 & .050 & .873 & .385 \\
\hline & LnExp & .044 & .020 & .074 & 2.188 & .031 \\
\hline
\end{tabular}

a. Dependent Variable: Lnincome

If the expenditure increases by one percent on improved seed the production will increase by 0.86 percent. All other variable remaining at the same level

In this table, coefficients show the impact on the ion production of rice in the selected area. If the expenditure increases one percent on plow the production increase by 0.098 percent. The fertilizer has more impact on the production which increases by 0.60 percent with a one percent increase in fertilizer expenditure all other variables remain constant. If a one percent increase has been done in all other variables they show the impact with the percentage in labor 0.52, Seed 0.63, Education 0.013, pest 0.15 , and experience increases production 0.04 . The variables in the study determine the good impact of the production of rice hence the proper use of these variables can increase the income of the farmers. The increased income will improve the socio-economic conditions of the farmers. The farmers can exit from the trap of poverty in Pakistan especially in rural areas of Pakistan.

\section{Conclusion}

Rice production is a major cash crop of Pakistan. Larkana is rich in this crop. This study has been conducted to determine the variable of production for rice crops for the enhancement of farmers' income to reduce the poverty in rural areas. Data collected with the help of a questionnaire, a sample size of one hundred were selected with a stratified sampling method. The result revealed that the family size of the farmer was large the education of the farmer was mostly up to metric level. The experiences of the farmers were better. The income level of the farmers mostly up to $25,000 /-$, the average income was 53,960/-. According to the regression model data was reliable. The variable explanation value was 0.914, which shows the good impact significance value of the model is 0.000 , which is less than the required value of 0.05 . All the variables were positive and show an impact on rice production. The incomes of the farmer show that there is still a need to improve the system of agriculture, which will improve the productions as per the potential. The increased income will improve the living standard of farmers.

Based on the study results this study suggests that the rice crop in this area must be focus to improve the per acre yielded. A microloan scheme for farmers will be helpful for them to purchase improved quality seed, fertilizer, and other inputs at a low cost. Training for new methods will be helpful for farmers to increase yield which will improve the income of farmers.

\section{Limitation of the Study}

This study has been conducted in a limited area due to financial constraints. It should be on a large scale for more results which will be helpful for policymaking. 


\section{References}

Africa Rice Center (Africa Rice) 2011 Boosting Africa's Rice Sector, a Research for Development Strategy 2011-2020. Cotonou, Benin.

Ali, M. and M. A. Chaudhury (1990), Inter-regional farm efficiency in Pakistan's Punjab: A frontier production function study. Journal of Agricultural Economics, Volume 41, pp. 62-74.

Akinbile, L. (2007). Determinants of productivity level among rice farmers in Ogun State, Nigeria. Paper presented at the Eighth African Crop Science Conference Proceedings

Conteh, A.M.H., Yan, X., and Sankoh, F.P (2012) The Influence of Price on Rice Production in Sierra Leone. Agricultural Sciences 3(4), 462-469.

Emongor, R.A., Mureith, F.M., Ndirangu, S.N., Kitaka, D.M and Walela, B.M (2009) The Rice Value Chain in Kenya Concerning Rice Producers. KARI, Nairobi. Government of Pakistan (2006), Economic Survey of Pakistan 2005-06. Finance Division, Islamabad.

GoP. (2015). Economic Survey 2014-15. Finance Division, Economic Advisor's Wing, Government of Pakistan, Islamabad

Hussain, S. T., \& Ishfaq, M. (1998). Dynamics of Agricultural Productivity and Poverty in Pakistan.

Memon, N. A. (2013). Rice: Important cash crop of Pakistan. Pak. Food J, 21-23.

Mundlak, Y., Larson, D. F., \& Butzer, R. (1997). The determinants of agricultural production: a cross-country analysis: World Bank Publications

NIPS. (2016). National Institution of Population Studies. Islamabad, Pakistan.

http://www.pbs.gov.pk/ 